\title{
Teaching English to Young Learners: Second Language Acquisition or Foreign Language Learning? - A Case Study
}

\author{
Carmen Manuela Pereira Carneiro Lucas ${ }^{1}$ \\ ${ }^{1}$ Universidade de Trás-os-Montes e Alto Douro, Portugal \\ Correspondence: Carmen Manuela Pereira Carneiro Lucas, Universidade de Trás-os-Montes e Alto Douro, Portugal.
}

Received: November 3, 2021

Accepted: November 21, $2021 \quad$ Online Published: December 10, 2021

doi:10.5430/wjel.v12n1p50

URL: https://doi.org/10.5430/wjel.v12n1p50

\begin{abstract}
A well-known, long-standing and heated debate across the literature concerning applied linguistics is whether within the classroom teachers are dealing with second language acquisition or second language learning. This controversial issue is especially relevant for contexts where English is learned as an English as an Additional Language (EAL) as in Portugal. This is particulalry important at a national level, where English is currently taught as a compulsory subject across primary education, with minimal input.

However, the English language curriculum, its pedagogy, and assessment are not anchored on Content for Language and Integrated Learning (CLIL) principles, hence resorting mainly to the students' mother tongue. As we move towards identifying and synthesizing best pedagogical practices for Teaching English to Young Learners, it is key that we seek a deep understanding of the most effective teaching strategies to foster second language acquisition. As the matter of fact, second language acquisition and overall literacy development have long been considered key to young learners of English, as a strong and solid primary education is critical to ensuring their long-term academic success (Snow, Burns, \& Griffin, 1998). Nonetheless, one major issue concerning primary English langauae teaching is the overwhelming lack of CPD opportunities and research-informed teaching, thus resulting in English language teachers' unsufficient pedagogical preparation, leading in turn to students' disengagement within the second language learning process.

Therefore, this paper seeks to explore whether exposure to English-only language lessons, through cross-curricular work sets a viable and solid path for second language acquisition in contexts where it is commonly believed that it is only possible to learn English as a set of isolated words.

As methodology for the present study there was resort to children's literature, language games and to an English-only classroom environment to simulate a bilingual education classroom. Within storytelling and cross-curricular work, key vocabulary was taught, hence working the language both at word and sentence level.

The findings, based in students' samples of work, do illustrate pedagogical practices which demonstrate successful second language acquisition, namely morpheme order acquisition, even with minimal exposure to the target language.
\end{abstract}

Keywords: teaching English to young learners, second language learning, second language acquisition, content for language and integrated learning (CLIL), pedagogy, teacher agency

\section{Introduction}

Research on second language acquisition (SLA) has expanded enormously since its inception, thus addressing a wider range of topics, questions and multiple methodologies. As new theories and research have emerged on language, and on learning, their application to the study of SLA has been productive. They have shed light on "developmental regularities, as well as opening up new lines of inquiry on second language (L2) development" (Pica, 2005).

Within SLA research, in recent years, there has been an unprecedented increase not only in the number of young learners (YLs) and their teachers, but also in the amount of language policy documents, teachers' handbooks, teaching materials, and empirical studies devoted to the topic of early foreign language learning (Nikolov, 2011; Djigunovic, 2012; Barrett et al, 2020). 
The most frequently researched target language (L2) is English, as a consequence, early language learning and teaching has become one of the key areas in applied linguistics and language pedagogy characterized by multiple research methods (Nikolov, 2009). This is because young children seem to have a special gift for learning language (Pallier et al, 2003). In addition, several studies have established that the age of acquisition of a first or a foreign language is the key determinant of ultimate proficiency (Oyama, 1976; Newport, 1990; Mayberry \& Eichen, 1991; Fledge, 2001).

Second language acquisition and the subsequent L2 literacy development are essential to young children's cognitive and social development. For all students, a strong and solid early education in a second language is fundamental to ensuring their long-term academic success. According to Snow, Burns \& Griffin, (1998), "academic success, as defined by high school graduation, can be predicted with reasonable accuracy by knowing someone's reading skill at the end of grade 3". As a consequence, improving reading programmes in early childhood and primary classrooms is crucial to making sure that all students read at grade level by the third grade. For young learners of English who are speakers of other languages (ESOL), the challenges of second language acquisition and the corresponding literacy development and are even more demanding as they are learning a second language (English) in a non-all-English environment where they 'only' need the language to function in school.

\subsection{Teaching and Learning Languages in Europe}

In 1995, through the publication of the White Paper, it was advocated in its fourth general objective that school systems should aim to help all learners to become proficient in three European Community languages (the $1+2$ formula: mother tongue plus two foreign languages). Added to this, it has also been recommended the introduction of the first foreign language in preschool education, so that it could be developed throughout the primary level schooling and the second foreign language to be introduced at the secondary level of education.

Afterwards, in 2001, this was strengthened with the publication of the Common European Framework for Languages (CEFR, 2001), thus advising intercultural awareness and plurilingual education. Being here understood as an intercultural language, English is a worldwide language (EWL), which is due to "globalisation, rapid expansion of information technologies" and 'huge waves of immigration into the UK', thus explaining why there has been an explosion in the demand for English worldwide (Pemberton, 2008). This view has also been supported by Carter \& Nunan (2005: 2): "English no longer belongs to the United Kingdom, not to the United States. It is an undeniable diverse resource for global communication."

Within this global linguistic environment, we should question, then, how are European citizens learning languages across Europe? On this matter, in 2008 the Council of Europe published a report entitled Key data on teaching languages at school in Europe, where it was provided information regarding teaching foreign languages in Europe. In relation to teaching foreign languages, it is possible to state that within compulsory education, foreign languages are being introduced at earlier stages of the curriculum. The fact that children are being entitled to learn foreign languages at earlier stages of the curriculum is related to political and economical reasons, within the underlying assumption that language competency will increase the opportunities within the labour market. Within this view, at a national context, the privileged role of teaching and learning foreign languages has been emphasized in the European Councils in Lisbon (2000). Afterwards the European Council in Barcelona (2002) identified five crucial skills towards knowledge building, namely foreign language competency. Therefore, and as already stated, representatives of the European Commision highlighted the need of taking action in order to develop basic skills, thus enhancing the teaching of at least two foreign languages besides the mother tongue (1+2 formula) at increasingly earlier stages of the curriculum, within the course of primary education. Within these plurilingual language policies, language competence has been defined as a 'key-skill', a concept adopted by the European parliament and by the Council of Europe (2006), thus strengthening the view of early foreign language teaching, within compulsory education.

Within the European perspective, learning languages earlier is understood as a contribution towards the building of a more comprehensive society, thus developing cognitive skills whereas at the same time reinforcing native language skills, such as reading and writing (EC, 2005: 3). Therefore, recommendations on early teaching and learning have been reinforced. Besides Portugal, other European countries operate with different linguistic environments, also following the Council of Europe recommendations, also emphasizing active citizenship, key towards better social integration and higher levels of employment (CE, 2006: 13). As a consequence, it might be stated that in recent years Europe has been recommending and highlighting language learning at earlier stages of the curriculum namely in the first years of primary school education and also in preschool education. These linguistic policies are aimed at developing in citizens communicative skills, defined as 'the ability to understand, express and interpret concepts, thoughts, feelings, facts and opinions, through oral and written language" (CE, 2006: 4). 
Within this perspective, we should also highlight the Common European Framework of Reference for Languages (CEFR) (CE, 2001), thus providing a basis for curriculum planning and foreign language approaches, tests and textbooks across Europe. Putting in the forefront as main goals the enhancement of a more united Europe, through the implementation of common practices towards foreign language teaching and learning, the CEFR presents a wide and practical description of what learners should learn through their foreign language education so they can become proficient in foreign languages. First and foremost, the CEFR defines 'skill' as a communicative skill, with an understanding of 'what makes the individual able to act through resource to linguistic knowledge and instruments.' Within this definition we should question then, what skills should be young citizens equipped to in order to become 'full' citizens, within a European viewpoint?

\subsubsection{The CEFR Common Proficiency Levels}

The Council of Europe, through the publication of the CEFR (2001) has established a set of competencies to be developed within young citizens. Added to the fact of stating common language proficiency levels, the CEFR identifies a set of prior skills such as intercultural, existential (i.e. learner attitudes, openness towards foreign language culture; motivations, values, beliefs, cognitive styles, personality), ability to learn (learning how-to-learn skills), language and communication awareness; general phonetic and awareness skills; heuristic skills (CEFR, pp. 108-109). Afterwards, in terms of linguistic proficiency, the CEFR sets six general linguistic ranges: A1, A2, B1, B2, $\mathrm{C} 1$ and $\mathrm{C} 2$. Thus, $\mathrm{A} 1$ and $\mathrm{A} 2$ are the most basic users.

Within A1 and A2 levels, the CEFR (2001: 110) states that learners should be able to:

"State simple expressions and needs of a concrete type. Can produce brief everyday expressions in order to satisfy simple needs of a concrete type: personal details, daily routines, wants and needs, requests for information. Can use basic sentence patterns and communicate with memorised phrases, groups of a few words and formulae about themselves and other people, what they do, places, possessions etc. Has a limited repertoire of short memorised phrases covering predictable survival situations; frequent breakdowns and misunderstandings occur in non-routine situations"

Further at the B1 level (CEFR, 2001: 110), it is considered that the learner: "has enough language to get by, with sufficient vocabulary to express him/herself with some hesitation and circumlocutions on topics such as family, hobbies and interests, work, travel, and current events, but lexical limitations cause repetition and even difficulty with formulation at times". Moreover, the most proficient language users are placed within the levels B2, C1 and C2, respectively, meaning that the $\mathrm{C} 2$ user has enough mastery of the language, also showing no signs of having to restrict what he/she needs to say. Bearing all these CEFR competencies in mind, within the citizenship agenda, European countries have started implementing two foreign languages at increasingly earlier stages of their curriculums, most often throughout the primary level of schooling. However, some countries are already able to provide some results regarding the introduction of foreign languages in preschool. This closely links with the view that in such a new world order, education for global citizenship through language education is essential in preparing our children and young people to live together in an increasingly diverse and complex society and to reflect on and interpret fast-changing information. One way of achieving these dimensions is through the use of foreign language education holistic approaches as a contribution to the young citizens' global education. We should question, however, how can these 'bigger' goals reach learners across the foreign language curriculum?

\subsection{Second Language Education Through the Use of Holistic Approaches for Global Citizenship}

Bearing the previous question in mind, we shall now consider narrower recommendations in terms of early foreign teaching and learning. In this respect, we should mention the report presented by Edelenbos, Johnstone and Kubanek (2006) in relation to some principles that should be respected to teach languages to young learners. This report resonates with the objectives of the Action Plan (2003), derived from decisions previously made in Lisbon and Barcelona, in regard to the knowledge and importance of foreign language teaching and learning. The provided document is grounded in data collected in European countries in preschool and primary school, thus suggesting evidence for good practice as well as some pedagogical implications.

The first implication concerns the profile of foreign language teachers, namely: the knowledge of the foreign language, the awareness of the principles underlying language acquisition, the ability to analyse and describe the language and appropriate pedagogical skills towards young learners. Further the report identifies some key recommendations bearing in mind successful language projects for teaching foreign languages to young children. Before immersing ourselves in these specific recommendations, we consider appropriate a brief look into how other countries (in Europe and outside the European space) operate in terms of bilingual and multilingual education policies. 


\subsection{European Countries Linguistic Environments}

European countries operate within various linguistic environments that influence foreign language programme choices. As such, it is usual for typical multilingual countries, with two or more official languages to introduce teaching several languages in the course of primary education. For example, in Ireland two first official languages are introduced (English and Irish) and then, on the pilot project basis, another modern or foreign language, French, German, Spanish or other.

For example, in terms of learning foreign languages in preschool, the Basque Country has been resorting to integrated foreign language learning approaches, thus working core curriculum subjects and the foreign language simultaneously (Ball, Kelly and Clegg, 2016)). Thus, through resort to Basque-Spanish bilingual programme, Basque instruction that develops Basque reading and writing skills is not just developing Basque skills, it is also developing at deeper conceptual and linguistic proficiency that is closely related to the development of literacy in the majority language (Spanish). Therefore, by learning content subject through the foreign language the programme is actually building on learners' previous knowledge and overall literacy (Cummins, 2011). Hence in the context of the $21^{\text {st }}$ century global society, Knowledge is understood as emergent, in the sense that "no one controls it, and no one can master it once and for all" (Resnick, Asterhan \& Clarke, 2015: 125). Added to this, the new evidence about how people learn has led to new conceptions of teaching and pedagogy. In line with this, Coyle (2008), during a research interview, at the School of Education, University of Nottingham, has defined Pedagogy as:

“(...) having a deep understanding of the theories of how people learn and being able to apply those theories into practice, which enables learning to be as efficient and as effective as possible given the contextual variables including age and ability so the individual is concerned. (...) Pedagogies are also politically and culturally linked as well as socially linked. So it is a socio, political, cultural phenomenon as well" (lines 40-47).

With the new millennium and within the knowledge-driven society, with the new conceptions of knowledge and competence, pedagogical methods are sought that are more likely to engage students in more active interpretation of what they listen, read or explanation of what they observe. In turn, these advancements make the more traditional curricular methods no longer appropriate when faced with the emergence of complex systems. The world, here understood as a complex system, where schools and educational systems are a part of it, are thus challenged to reinvent curriculum in a reply to the multicultural world the Earth is today. Therefore diversity, complexity, mobility, connectivity, choice and multiculturality, along with the growth of democratic systems, require change in educational systems. As a consequence, education is no longer a tool uniquely targeted at the development of mechanic drills, but it rather should be faced in a lifelong learning perspective, where people interact with other learning cultures, thus controlling metacognitive skills, preparing themselves for an uncertain and complex world.

Previously, in the 1970s, learners' knowledge was known under the term skills, thus targeting key areas such as observing, reading a map, asking for information, applying a formula into a specific context. More recently, the developments of these areas are known as broad literacy skills or competency (Roldão, 2005; Cameron, 2010). In more recent years, the term 'literacy' has embraced several areas of learning, ranging from technological, economic, social, and global changes (Lankshear \& Knobel, 2011). Thus we have the emergence of "critical literacy", a skill that should be developed as early as possible in young citizens

Therefore knowledge building or competency building should be planned accordingly to a holistic view of the goals and purposes to achieve. For example, in a lesson plan where learners are to learn about the British currency, objectives should embrace the sociocultural dimension, thus considering not only learners' ability to use the pound (£) but also to become aware of the possible contexts where they would use it, thus resorting to imaginated intercultural contact (Rivers, 2011).

In line with Europe's languages policies, research studies carried out on the topic of early teaching and learning of foreign languages have been gathered in an overview presented by Nikolov \& Djigunovic (2011). In their review the authors state:

"In recent years, there has been an unprecedented increase not only in the number of young learners (YLs) and their teachers, but also in the quantity of language policy documents, teachers' handbooks, teaching materials, and empirical studies devoted to the topic of early foreign language learning" (Nikolov \& Djigunovic, 2011: 1).

As a consequence, early language learning and teaching has become one of the key areas in applied linguistics and language pedagogy characterized by multiple research methods (Nikolov, 2009). In turn these topics are, in some 
settings, closely related to bilingualism or plurilingualism, ranging from the language specific features to the cognitive and metacognitive elements involved in the language learning processes.

However and in cases where children have limited contact with the foreign language, one way of making learners aware of the intercultural dimension whereas at the same time fostering overall literacy development is through the use of narration and children's literature (authentic storybooks). In line with the view promoted by Action Plan (2003), early foreign teaching and learning projects should bear in mind the following premises:

1. Research - throughout the period of implementation, research must be assured from the early beginning until the project assessment and its reconceptualisation;

2. Parental involvement, thus supporting foreign language learning, thus understanding the goals of early foreign language education;

3. Progress, there should be a sequencing progress among the several grades of compulsory teaching, in order to enhance and motivate future foreign language learning;

4. Time - the time devoted to learning, especially oracy, shall be increased. Daily contact with the language would be an ideal condition;

5. Teacher training - this area is identified as an area where further training is required for teaching young language learners, thus establishing a suitable teacher profile to the primary teaching level of education.

6. Learning for all, by doing research projects in order to develop foreign language learning strategies among low-socioeconomic (low-SES) children, and for those who reveal more difficulties in FL learning.

7. Appropriate approaches - teaching young learners is not just a mere adaptation of the older learners' curriculum. It is therefore crucial to create supportive learning environments, resorting to storytelling as entitling children with an appropriate framework for listening, talking and interacting;

8. Linguistic diversity - although English own the status of being the international language of communication, thus making its learning important, it is also necessary to foster plurilingualism, thus enhancing other widely spoken languages.

9. Supervised research - the carried research shall be effective and supervised in order to be evaluated, thus searching other possible paths, aiming at better teaching and learning.

10. Potential dangers - without appropriate resources and supportive pedagogies, foreign language teaching in early primary education and preschool might turn into a 'poisoned gift', since poor performances might lead to failure and cast de-motivation in future foreign language learning (Action-Plan, 2003: 19-27).

\subsubsection{Second Language Acquisition (SLA) and Interlanguage Development: Morpheme Accuracy Order}

While a significant body of research in SLA has focused mainly on describing the learner's interlanguage and identifying sequences and patterns of development, such is not the case within the national, Portuguese context. Most lileky due to the lack of Continuous Teacher Training Opportunities and research-informed teaching, the vast majority of teachers delivering English to Young Learners in primary schools clearly demonstrate a disbelief in the potential for second language learnning within this early stage of Language Education. From the vast international research, a significant amount has devoted it attention to interlanguage development and the learning of English. Most interlanguage patterns reflect the learner's attempts at communication and learning, or at managing and processing L2 input. Others reflect grammatical complexities or input frequencies that transcend individual L2's (Lightbown 1985, 2000; \& Pica 1994a).

In turn, as argued by Duarte (2016; 2019), García \& Leiva (2013) described translanguaging as both an act of bilingual performance and a pedagogical approach for systematically teaching multilinguals, by encouraging them to use the totality of their language knowledge to engage in educational learning. Added to this, the most widely studied and reported developmental sequences are the accuracy order identified in English grammatical morphology, and the identified sequences of L2 development, certainly shed light on how Primary Teacher of English to Young Learners can best tackle Young Learners students' struggles, successes and progress within language learning.

\subsubsection{Morpheme Accuracy Order}

Within this line of enquiry, regarding morpheme orders in children learning English as their first language, Dulay and Burt (1974) enquired to what extent L2 children reflected the morpheme accuracy order. In their study, the authors reported that children with different L1 native languages, who were learning English in a variety of classrooms, were asked to describe pictures that provided contexts to apply grammatical morphemes such as plural -s endings and verb 
functions. In futher studies, Krashen (1987), held across spoken and written samples of children, adolescents, and adults, regardless of $\mathrm{L} 1$, whether or not formal instruction had been part of the learning experience. The consistency of the morpheme accuracy order led to the view that SLA was a matter of 'creative construction,' and therefore much like FLA.

In a subsequent study, Ellis \& Han (1989) studied instructed learners of German L2, and found the same sequence of development. In addition, Pienemann \& Johnston (2008) applied the sequence to English, claimed that this a sentence internal movement as it reflects the learner's management of both subject and verb structures. More importantly, it should be highlighted Pienemann's Teachability Hypothesis (Pienemann 1984), where the autor has demonstrated that L2 learners can accelerate their rate of L2 learning if presented with rules for constituent movement that corresponded with their next stage of development.

\subsubsection{Second Language Play as a viable path to Second Language Acquisition}

Within second language teaching/second language acquisition, how to enhance the acquisition of the morpheme accuracy order is extremely important for learners of English, as in line with the CEFR levels, this constitutes the foundational linguistic background for language fluency, namely and ultimately, writing proficiency.

However, how to best approach this 'grammatical' dimension within English Language Teaching to Young Learners is a practically unknown element within the EFL Portuguese context and EFL syllabus design (Mourão, 2018; Lucas, Coyle \& Hood, 2020; Lucas, 2020).

One of the suggested and most effective ways to enhance second language teaching, besides cross-curriular work, is the resort to language play. This is mainly because language play gathers a unique integration between mental and physical activities that take place in a meaningful context, and also because language play is characterised by enjoyment, spontaneity, creativity, imagination and an absence of fear of failure and negative consequences (Cook, 2000; Darasawang \& Todd, 2012).

In language play, children represent and interpret the real world, build on and extend their schemata and construct and new knowledge. In order for language play and language learning take place, it needs to occur in an environment that is both child-friendly and enjoyable (Lantolf 2000; Smith \& Pellegrini 2008). As play is a spontaneous activity, it has been considered helpful for the development of language, also due to the fact that language play is free from fear and negative forces as well as a way for children to ease feelings of stress and boredom (Jrank 2010; Darasan \& Reinders, 2015; Whitebread \& Coltman, 2015).

More importantly, Verissimo et al (2017), in their study were able to demonstrate that there is a case for a critical period hypothesis (Lennerbeg, 1967), and that indeed exposure to language before the age of 7 allows for substantially better outcomes. Much research on grammatical processing in bilinguals has focused on the question of how the processing of grammatical phenomena differs between a native language (L1) acquired from birth and a second or nonnative language (L2) acquired later in life. Moreover, in another study, regarding the ideal age of acquisition (AoA), Bosh, Verissimo \& Clahsen, 2019 researched to what extent the initial Age of Acquisition affects grammatical processing, namely inflectional morphology, in bilinguals. They examined experimental data of more than 100 participants from the Russian/German community in Berlin, all of whom acquired Russian from birth and German at different ages. Using the crossmodal lexical priming technique, they investigated stem allomorphs of German verbs that encode multiple morphosyntactic features. The results revealed a striking AoA modulation of observed priming patterns, indicatiing efficient access to morphosyntactic features for early AoAs and a gradual decline with increasing AoAs. In addition, we found a discontinuity in the function relating AoA to morphosyntactic feature access, suggesting a sensitive period for the development of morphosyntax.

\section{Aims of the Study and Research Questions}

Bearing the previous theoretical framework in mind, the present study is set out to determine to what extent can the gramatical features of the language be incorporated in the syllabus for English Language Teaching, thus preserving Young learners' engagement withn the language learning process. Therefore, this study aims to investigate the most innovative pedgogic approaches to contribute to effective second langauge learning, with two main guiding research questions:

(1) Does early English learning experience contribute to morpheme acquisition order and improves second grade primary puplis' English learning outcome?

(2) How can EFL Teachers of Young Learners best include this dimension in lesson planning, without causing frustration to Young Learners of English? 


\section{Materials and Methods}

The corpus of the current study was prepared by the bilingual teacher/participant researcher, bearing in mind some of the principles from Content for Language and Integrated Learning (CLIL). "CLIL refers to situations where subjects, or parts of subjects, are taught through a foreign language with dual-focused aims, namely the learning of content and the simultaneous learning of a foreign language" (Marsh, 1994; 2015). CLIL was selected for the present study, as it was understood as an educational model for contexts where the classroom provides the only site for learners' interaction in the target language.

\subsection{Method}

\subsubsection{Context}

This study was carried out in a Portuguese primary school classroom, concerning the $2^{\text {nd }}$ grade primary education (all place and participant names are pseudonyms), which was located in a city centre area in the northeast Portugal, classified as a mid-SES setting, prior to the implementation of the national strategy for languages across primary schools. The pupils were predominantly mid-SES economic backgrounds, bearing in mind that they were attending a semi-private school, pioneer in "offering" children's parents the entitlement for their children to learn English, on a non-compulsory basis.

The school followed the national curriculum framework for L1 literacy development, which the participant researcher took into consideration, in clear articulation with the action-research plan to target key curriculum themes, such as social studies, mathematics and arts and crafts. The class' daily schedule started with individual literacy and mathematics activities as morning work, before the regular daily classes in content areas including English as a second language as the last taught subject of the day.

\subsection{Sites and Participants}

The school in the present study was considered as a mid-SES, high-achieving school according to state Department of primary state instruction and primary teacher reports. The sample for this study included the second grade of primary school children $(\mathrm{n}=84)$ (7 years old), attending EFL primary sessions in a Portuguese semi-private school. Research ethics were adhered to by following the British Education Research Association (BERA) that endorses the set of ethical principles agreed in 2015 by the Academy of Social Sciences (AcSS) through in-depth consultation with its member learned societies (including BERA).

\subsubsection{The L2 Pedagogic Approach Development and L2 research}

Studies exploring the effect that bilingualism has on language-related tasks have primarily focused on lexical retrieval (Morini \& Newman, 2019). As less is known about bilingual performance in other types of linguistic tasks, and specifically in tasks that involve processing speech in different listening environments, to understand different messages, listeners must simultaneously process competing sounds and rely on cognitive abilities and previously acquired linguistic knowledge to interpret the information that is being conveyed. Morpheme Order Studies (MOS) conform a set of highly influential studies in the field of first and second language acquisition. These studies were based on the assumption that there exists a universal and natural order for morpheme acquisition that all learners follow regardless of their background. The present paper aims to make a critical review of these studies by outlining the most significant ones in the domain of Second Language Acquisition (SLA) (Ramos, 2018). In his study, a smaller study has been carried out with the purpose of finding out in which order morphemes are actually acquired and to what extent L1 transfer can alter this order. Unlike Ramos (2018), the data I have gathered from pupils' assignments in class, was completed by learners in their English language lessons. I have assigned them at levels A1 and A2, in line with CEFR for a more comprehensive study.

\section{A Case Study Reinforcing the View of Stephen Krashen Towards Theory of Second Language Acquisition}

This analysis enabled me not only to determine which morphemes the students acquired first and which ones later but also to propose a possible order of acquisition that the participants could have followed, depending on the number of errors gathered in relation to each morpheme. After that, I have compared the order determined by this study to the one proposed by Krashen (1982) to check if these subjects adhered to the natural order of acquisition.

In the viewpoint of Krashen (1982), "the basic premise of natural order studies is that there may be a consistent order in which first and/or second language learners acquire proficiency in the use of grammatical morphemes, which are traditionally defined in linguistics as "minimal unit[s] of meaning" (Johnson \& Johnson, 2006). These units and their meanings may be lexical or grammatical. The sentence "I like cereals and milk for breakfast", "I have got a doll", for example, contain a grammatical structure. The field of natural order studies are also known as functors (Kwon \& Han, 
2008). Similar sentences have been use in the context of this study as per the exemples from the worksheets.

Pupils' samples of own work/ results reveal that young English language learners actually followed accurately Krashen's natural order of acquisition and that interlingual transfer from their L1 was successful and as the matter of fact, corroborates the fact that the L1 plays a significant role on the acquisition of L2 morphemes, as in the case of Portuguese language the order of the words in affirmative sentences follows the English word order, which is a facilitating factor prompting $\mathrm{L} 2$ acquisition.

In line with the view from Krashen, the present study demonstrates that the best approaches for English language learners in the process of L2 acquisition are therefore those that supply comprehensible input in low anxiety situations, containing messages that students really want to hear. Therefore, for instance, if the teacher is teaching a song about meals, resorting to a Total Physical Response song (Asher, 1969) and wishes that students understand that the aim is learning about food, the teacher can convey the gesture/mimicry to make the language understandable, i.e. conveying comprehensible input.

In the same way, teachers can use 'realia' to develop and foster language acquisition, because if students are 'immersed' into the target language during class time, they will acquire the language spontaneously, without needing to translate the target language (Bala, 2015; Irfan et al, 2021). In addition, as argued by Bala (2015), using 'realia' into the classroom is one of the most effective ways to create an enjoyable class atmosphere and acquire the target language efficiently. For instance, while teaching the items about UK currency, it is better to provide pupils with actual Money samples to enhance their understanding. They see the components of the pennies and pounds, touch a real object and this helps them in obtaining the required knowledge comprehensibly. Other item such as actual clothes being placed in a rope can be used to teach the item 'clothes', as they see and listen the target word and becuase $i$ tis something meaningful for them, they'll acquire the target vocabulary.

In this study comprenhensible input clearly visible in the students written produced documents, thus resorting to language paly and familiar cartoons, such as 'the Simpsons', the Cookie monster and other friendly cartoons. These L2 language play methods do not force early production in the second language, but allow students to produce when they are 'ready', recognizing that improvement comes from supplying communicative and comprehensible input, and not from forcing and correcting production. Krashen (1982), which leads us to the comprehnsible Input hypothesis proposed by the same author.

This hypothesis is the author's attempt to explain how the learner acquires a second language, how second language acquisition takes place. According to this hypothesis, the learner improves and progresses along the 'natural order' from L1 when he/she receives second language 'input' that is one step beyond his/her current stage of linguistic competence. Indeed, Krashen further considers that the only instance in which the teaching of grammar can result in language acquisition (and proficiency) is when the students are interested in the subject and the target language is used as a medium of instruction. As a consequence, CLIL under the form of English Across the Curriculum is the ideal situation for English language learners in a monolingual environment, as it is the case of Portugal (Coyle \& Hood, 2010; Lucas, Coyle \& Hood, 2020; Lucas, 2020). These findings are particularly relevant for the Portuguese context and for primary English language teachers, as they set a viable path to second language acquisition, while preserving students' engagement and motivation within English language learning.

Within this framework, it should also be noted Cummins' Iceberg Analogy, where the author stands for a common underlying proficiency hypothesis, in that languages share a common lingusitics background whereas at the surface level, they are interdependent and develop mutually. 


\section{Common Underlying Proficiency}

\section{The Iceberg Analogy}

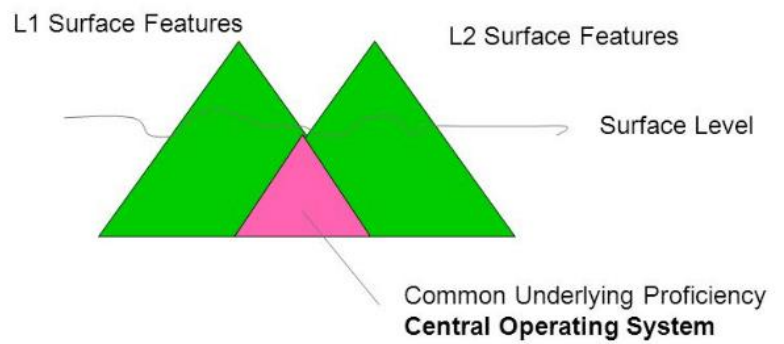

Figure 1. The Common Underlying Proficiency Hypothesis (Cummins, 1981)

The current findings are surprising substantiate that even with minimal input as $2 \mathrm{x}$ a week for a period of 50 minutes each, children are able to acquire an L2.

The content analysis procedures applied to the collected data, such as children's completed worksheets and the teacher's own materials, put in evidence the language view that this case study actually puts 'applied linguistics in action' and clearly shows that children as young as 7 years old can learn and master second language structures, thus leading to second language acquisition, thus providing them with a solid background for their future academic achievement. As mentioned previously, these data can be explained not only by the 'comprehensible input' hypothesis, but also by the 'common underlying proficiency' hypothesis proposed by Cummins $(1979 ; 1981 ; 2008)$, where the assumption is that languages share common features, only being diferente at the surface levels. This certainly adds up to our understanding and research on L2 acquisition, as there is an overall uninformed view that primary school children cannot acquire the L2 because they are immersed in a monolingual setting (Lucas 2020; Gundarina \& Simpson, 2021). While most often a buzzword is language awareness, this study sheds light into the process of acquiring a second language, while preserving the first, native language. One possible explanation for this might be that as children have settled the L1 structures they transfer those principles into the L2. In the following task pupils were required to read affirmative sentences in English (L2) and match them to the corresponding pictures. More challenging was when the speech bubble stated "I like cookies and milk" and students not only had to guess the meaning as matching and draw to the blank square, where they needed to draw the missing items. Language play was a constant dimension in the planning of English language lessons and, based on the data findings, we might assert that this strategy was effective in prompting successful L2 learning (Figure 2). 


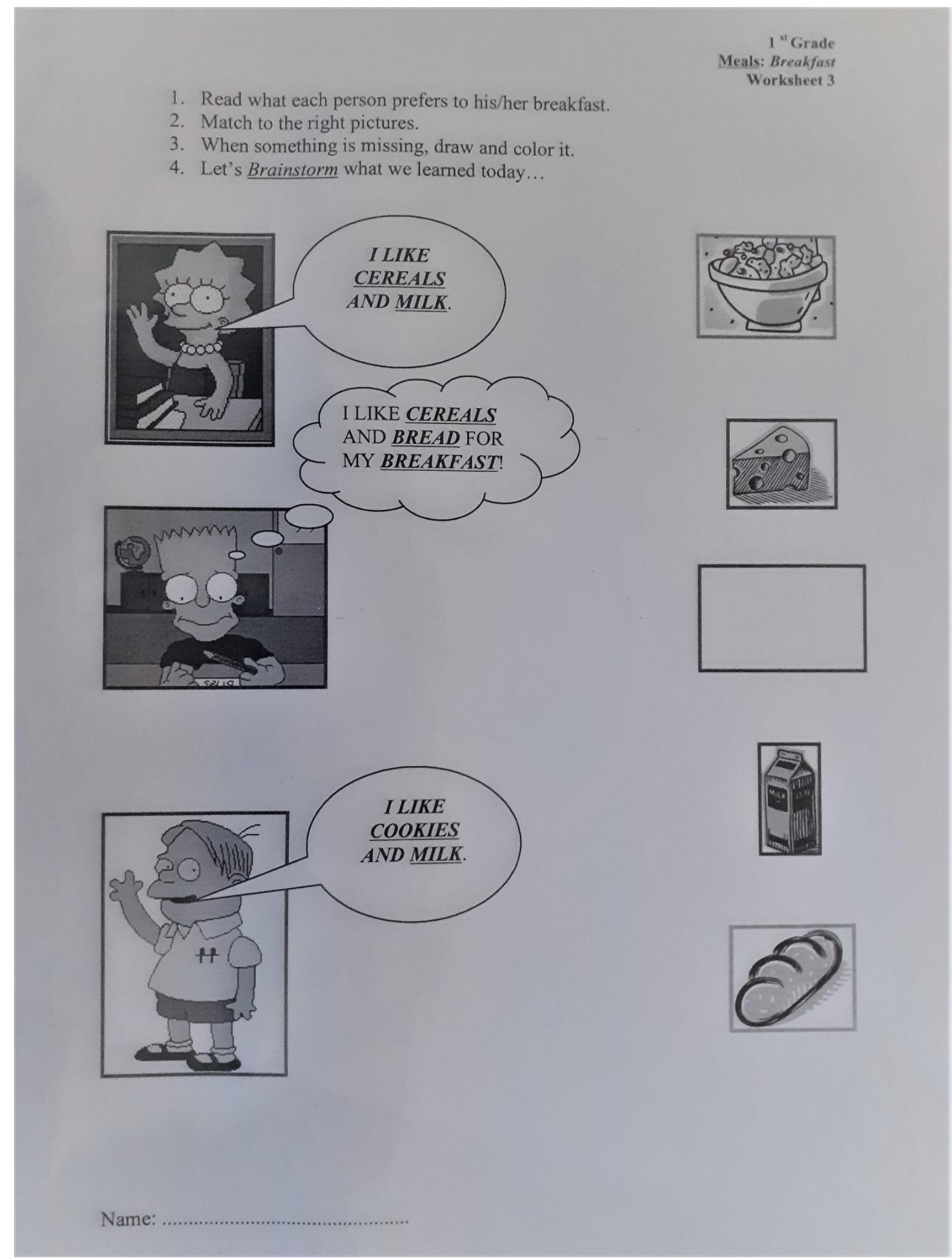

Figure 2. Enhancing Reading in na L2 through Language Play 


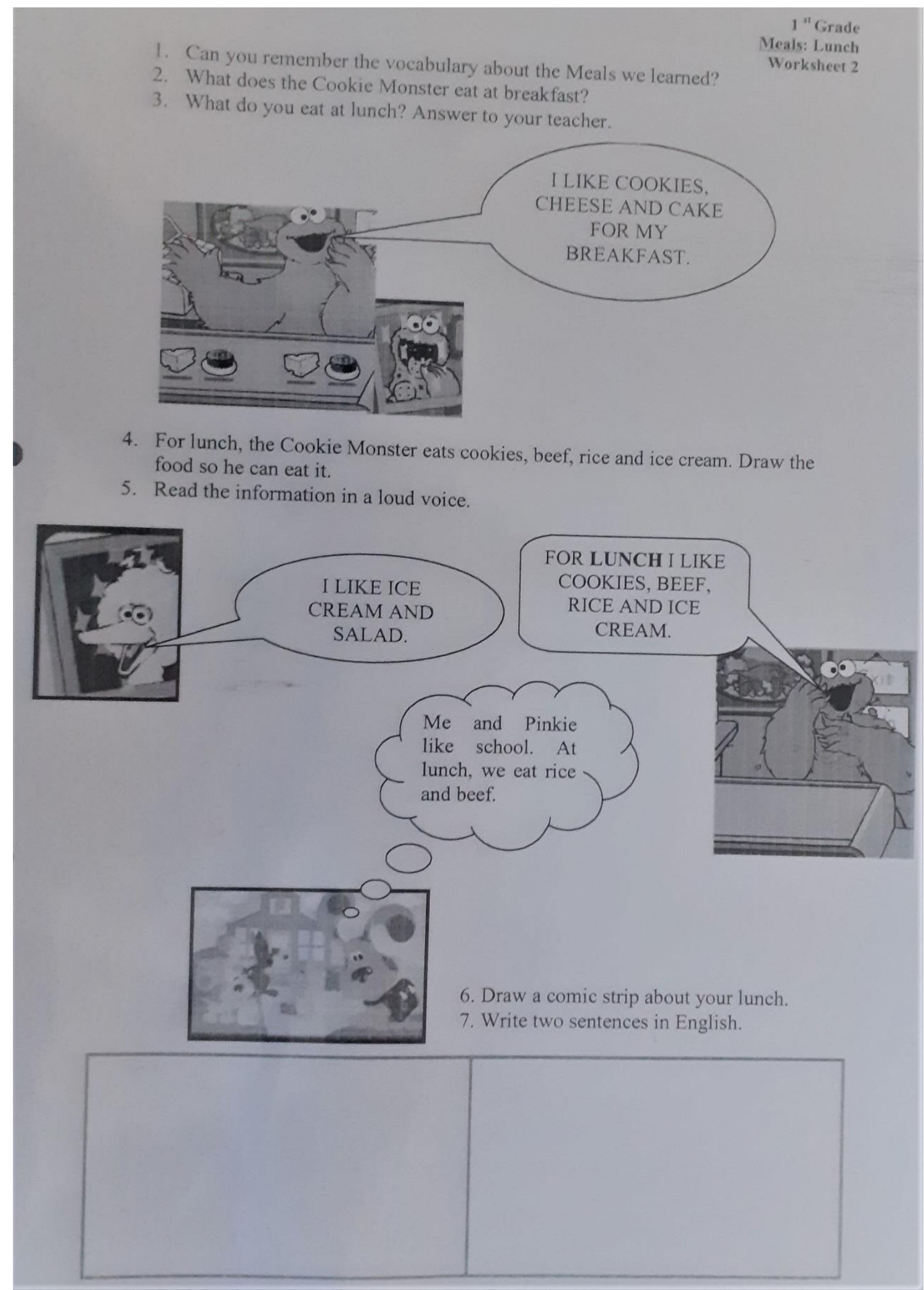

Figure 3. Enhancing Reading and Writing in the L2 through Langauge Play 


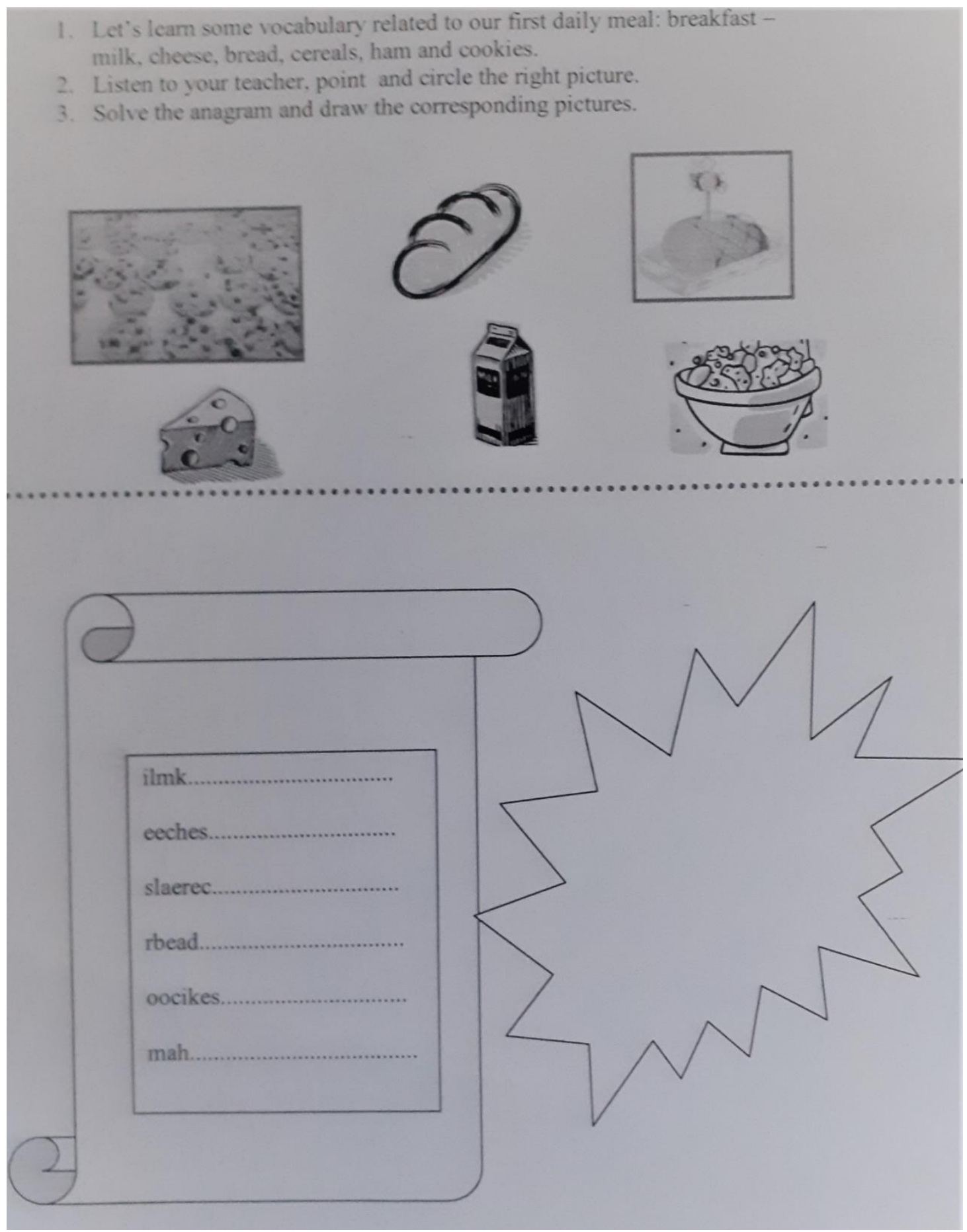

Figure 4. Enhancing L2 Writing through Jumbled Word Task

\section{CLIL and Cross-Curricular Work, through English Across the Curriculum}

Content for Language and Integrated Learning (CLIL) has been understood as a way of improving second language knowledge, in addition to triggering young primary school children's engagement into the language (Coyle, Holmes and King, 2009). Because subject contente is taught through the médium of a foreign, second langauge, it allows "experience with teaching content matter through more than one language is bringing new insights into improving 
general education programmes" (Baetens-Beardsmore, 2001). CLIL might be considered a type of additive or functional bilingualism (Lessow-Hurley, 2000; Baker, 2001), which aims to add a new language to the student' native language. According to Garcia (2009), this is "a model under which the second language is added to the person's repertoire and the two languages are maintained". The main differences between bilingual approaches and CLIL are: the consideration of the second language as an individual subject in the curriculum which is taught at the same time together with the other content subject. In order to follow CLIL premises, materials were cross-curricular designed. For instance, if children were learning Mathematical shapes in the L1 formal instruction curriculum, materials were designed as a paralell, targetting the key areas of learning and making learning more meaningful (Figure 5, Figure 6 and Figure 7).

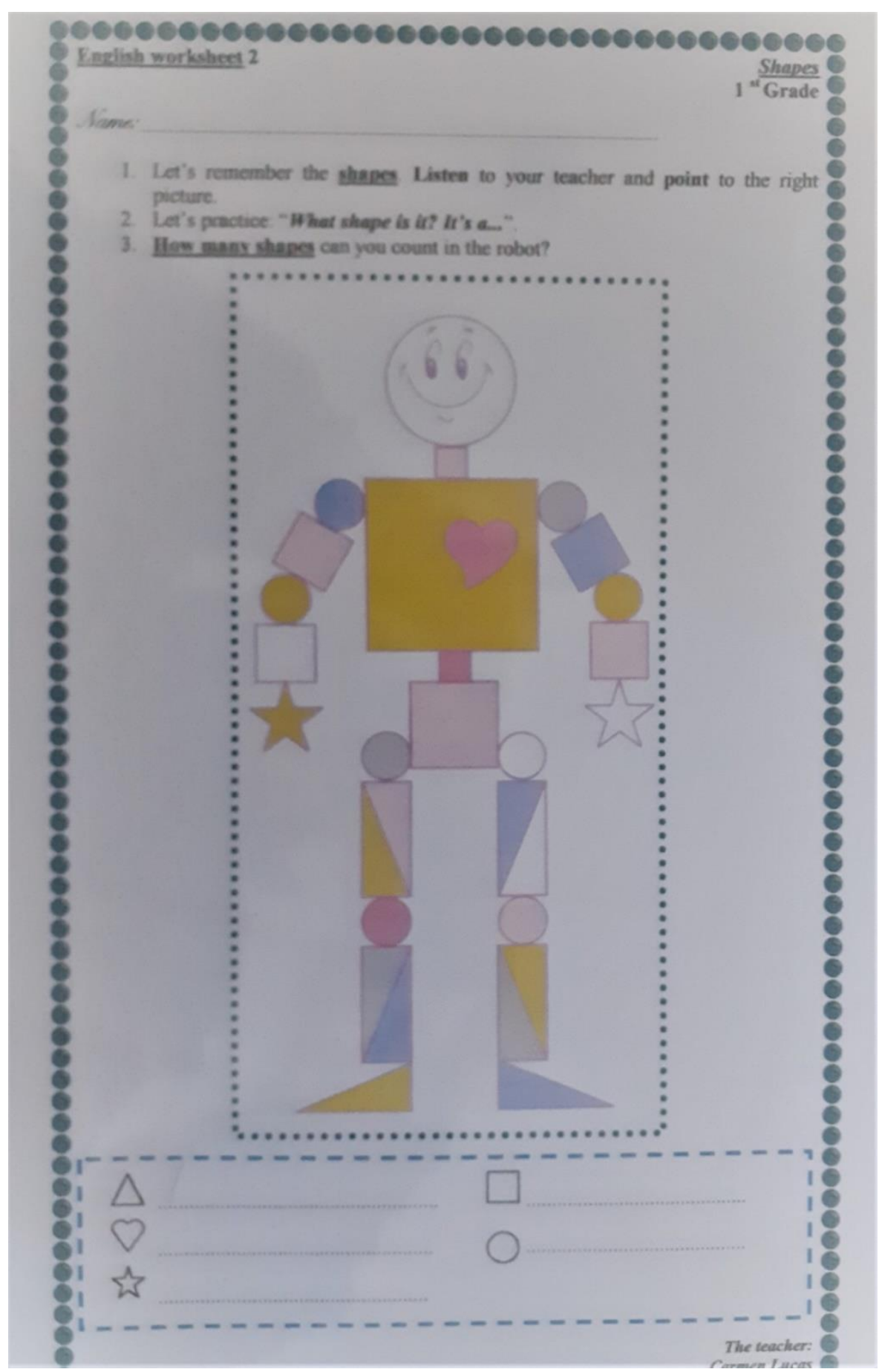

Figure 5. Enhancing Cross-Curricular Learning, targeting core curriculum areas: Mathematics 


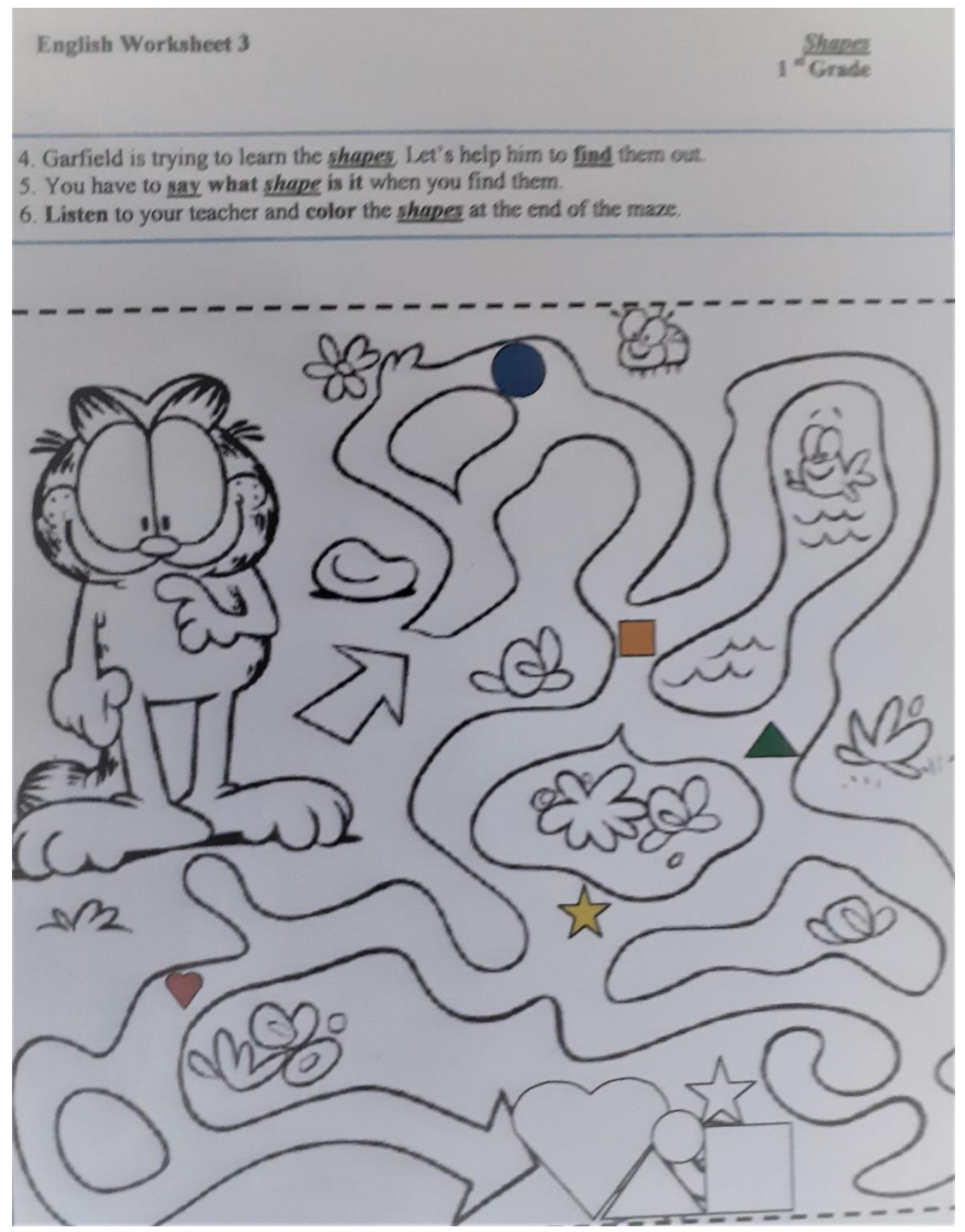

Figure 6. Enhancing Cross-Curricular Learning, targeting core curriculum areas: Mathematics 


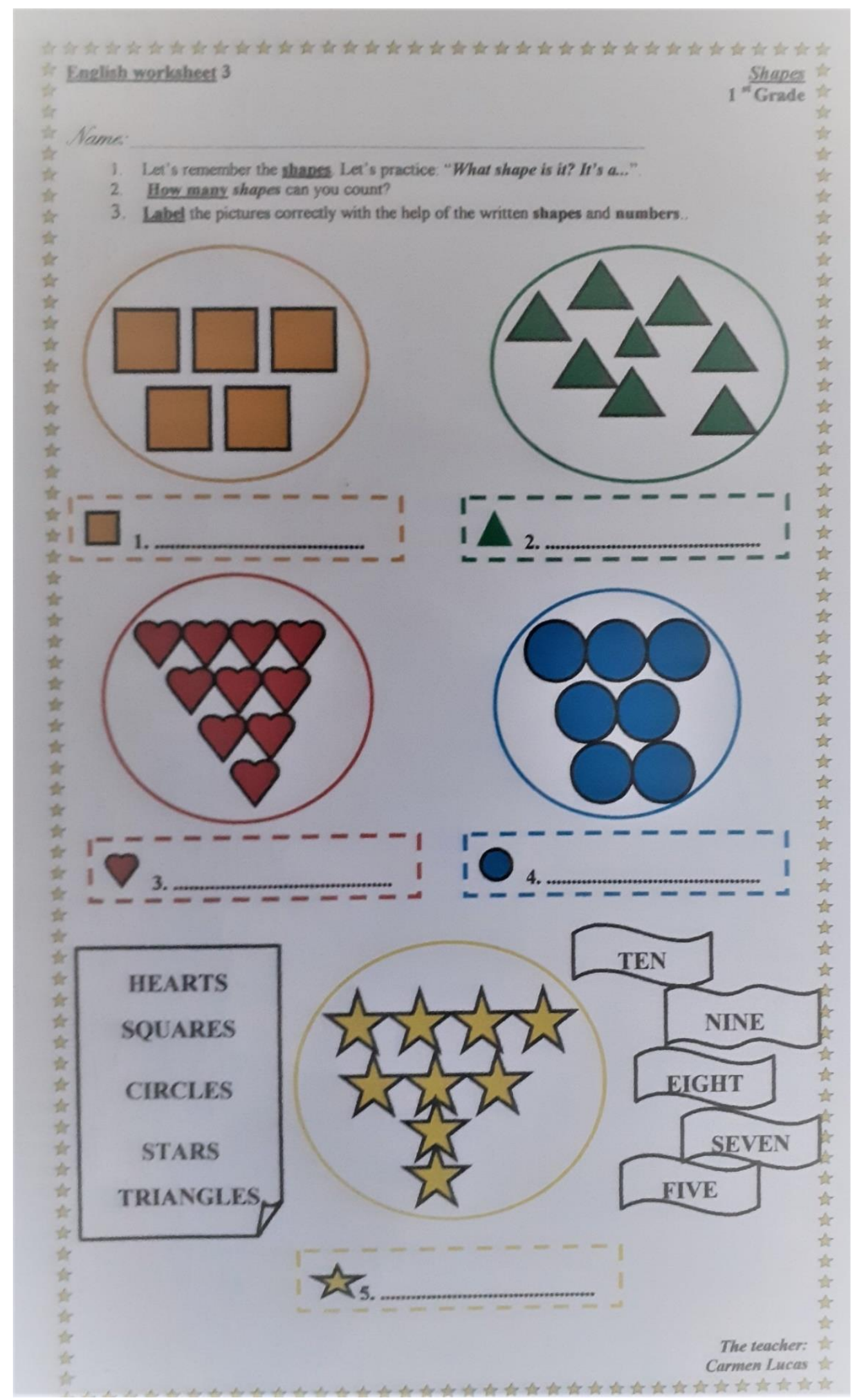

Figure 7. Cross-Curricular Work: Shapes, Numbers and Colours 


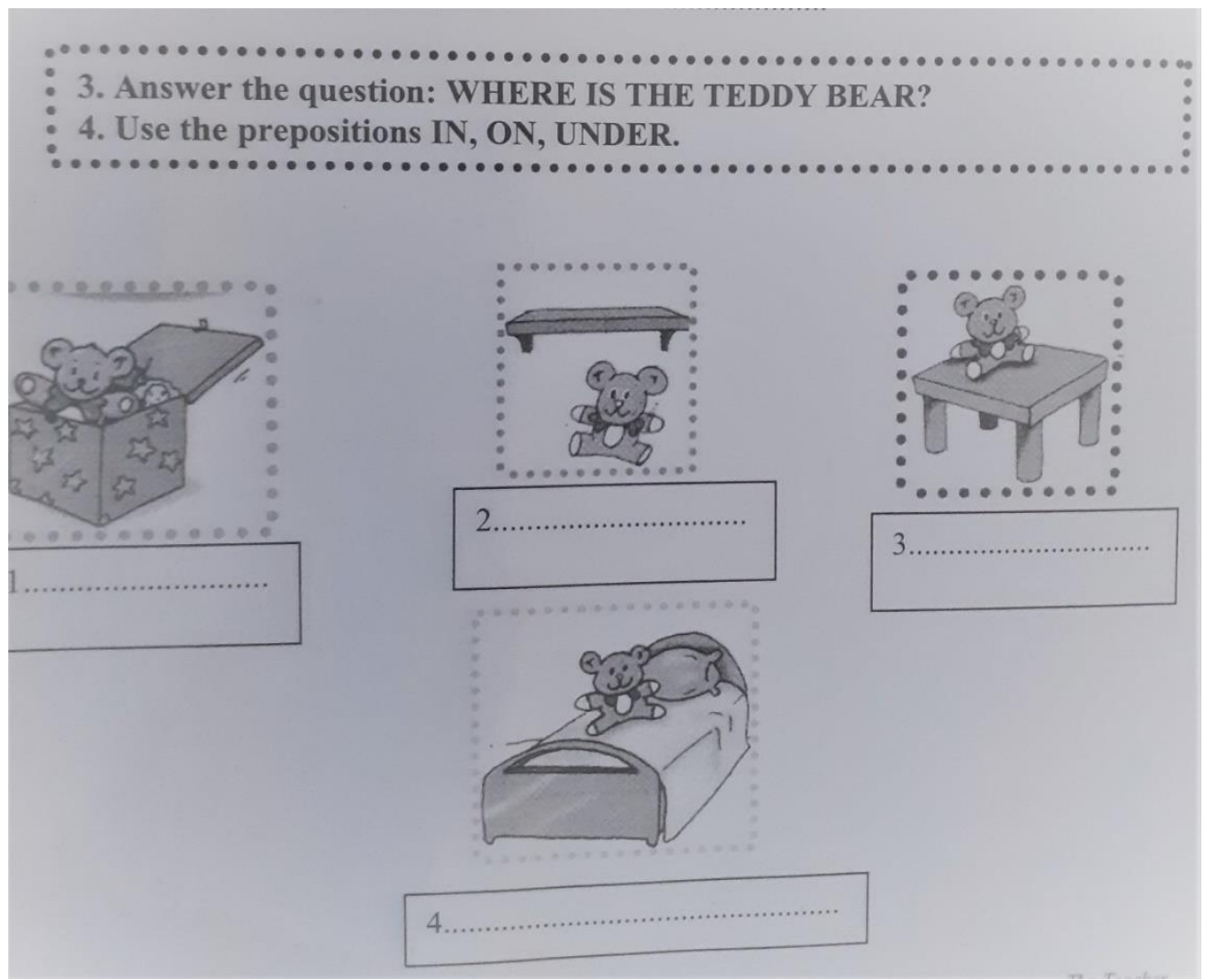

Figure 8. Teaching L2 Grammar thorugh raising awareness of Morpheme Word Order: Prepositions of Place

As it can be seen on Figure 8, students needed to answer the question 'where is the Teddy Bear'? Their answers should be:

1. The Teddy Bear is in the Box

2. The Teddy Bear is under the shelf

3. The Teddy Bear is on the table

4. The Teddy Bear is on the bed

Lessons' recordings and transcript demonstrated that children have done this task successfully.

\section{Findings}

\section{Enhancing Morpheme Word Order}

The central question of morpheme order studies was whether learners show a universal pattern in the acquisition order of morphemes. If present, a universal pattern could indicate the existence of a universal mechanism necessary to acquire language (Dulay \& Burt, 1973; Dulay \& Burt, 1974).

As it can be seen in Figure 10, Figure 11, Figure 12 and Figure 13 children were able to write partial and full sentences and draw/write the corresonding missing parts of the sentences, while using and respectinb morpheme work order. This certainly sets a viable path for successful L2 acqusition. The process was gradual, as first children were provided with certain anchors/scaffolds, such as the beginning and end of the sentence, and then anchors/scaffolds were removed in the last couple of sentences, where children had to write sentences in full (Vigotsky, 1978). This is indeed a remarkable achievement for English language learners in a Portuguese school setting, aged 7 years old, which is in agreement that children learning English as a foreign language can surely acquire the language strucutures required/morpheme order if and when provided with comprehensible input and sacffolding in the L2 acquisition process. Naturally the Vigotskian framework underlied this whole teaching and L2 acquisition process, where children were constatntly challenged and scaffolding provided whenever needed to avoid any sort of language anxity or furstation with the target language. 


\section{ZPD and scaffolding}

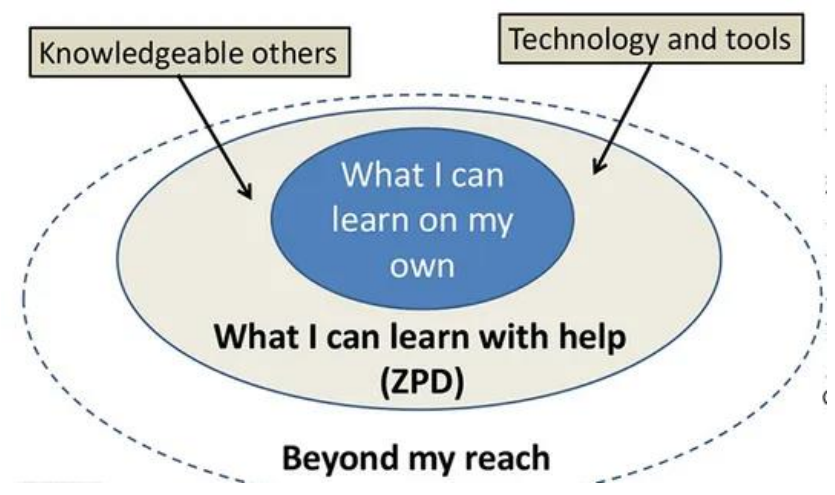

Figure 9. ZPD and scaffolding

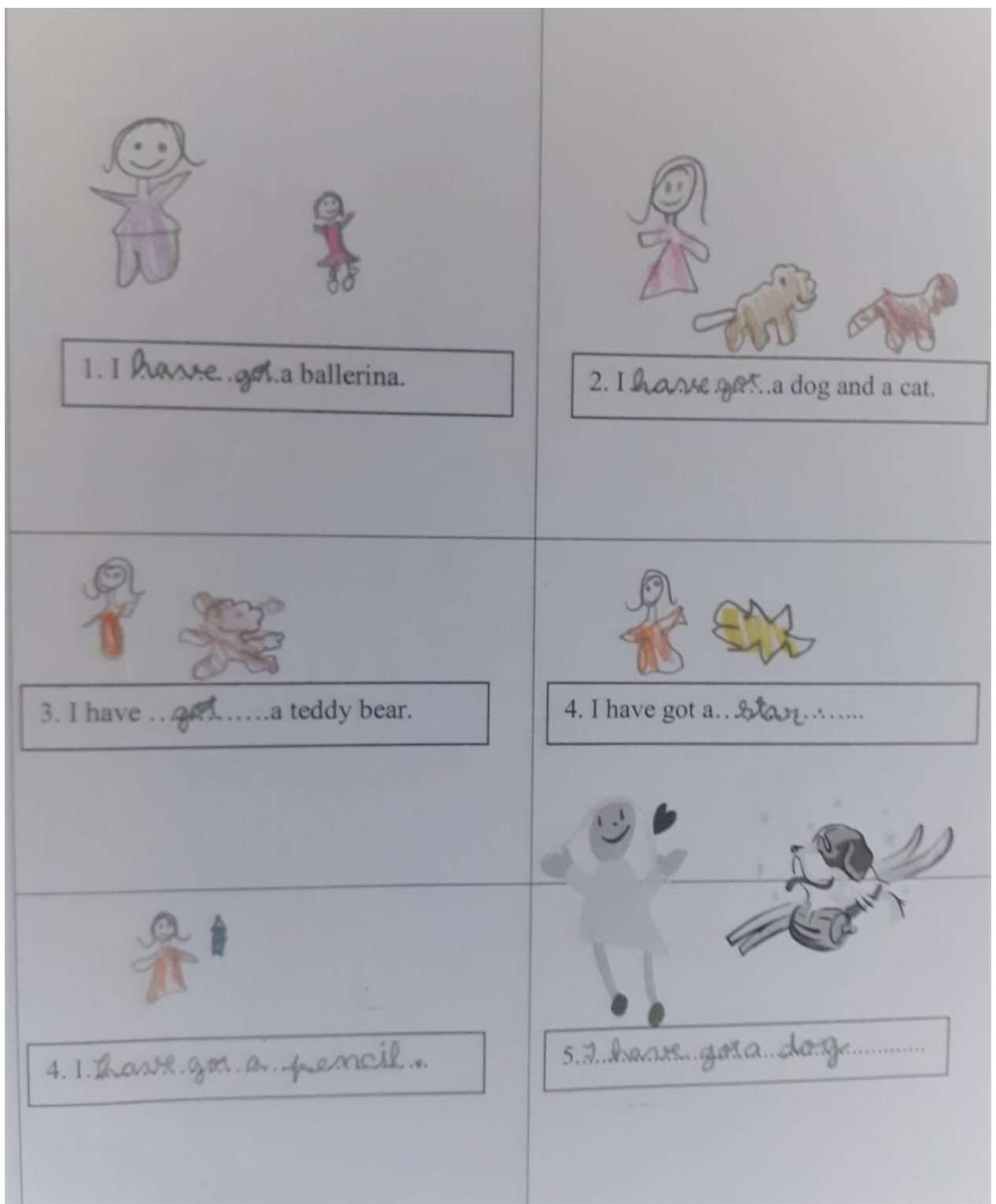

Figure 10. Teaching L2 Grammar thorugh raising awareness of Morpheme Word Order: verb Have Got 


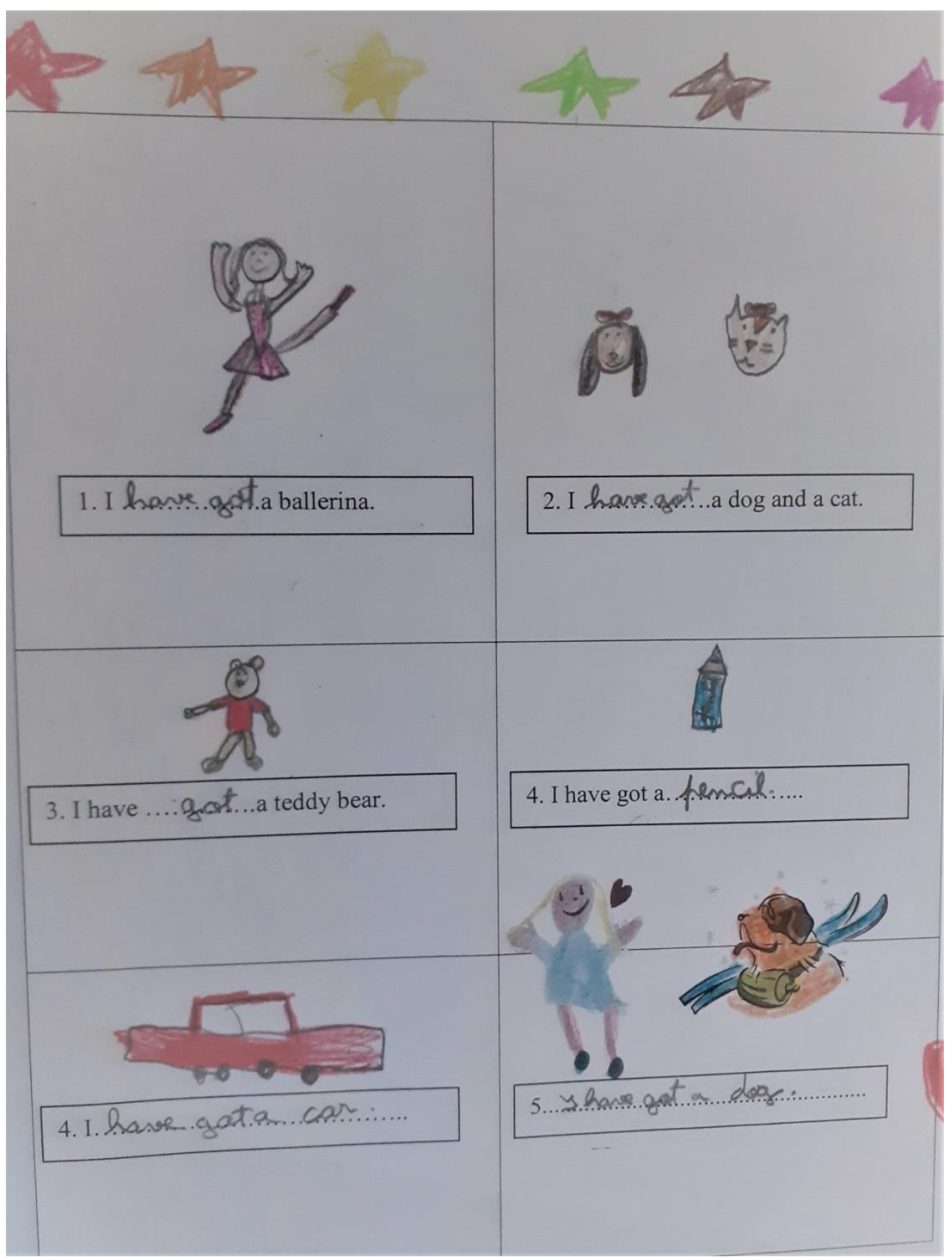

Figure 11. Teaching L2 Grammar thorugh raising awareness of Morpheme Word Order: verb Have Got 


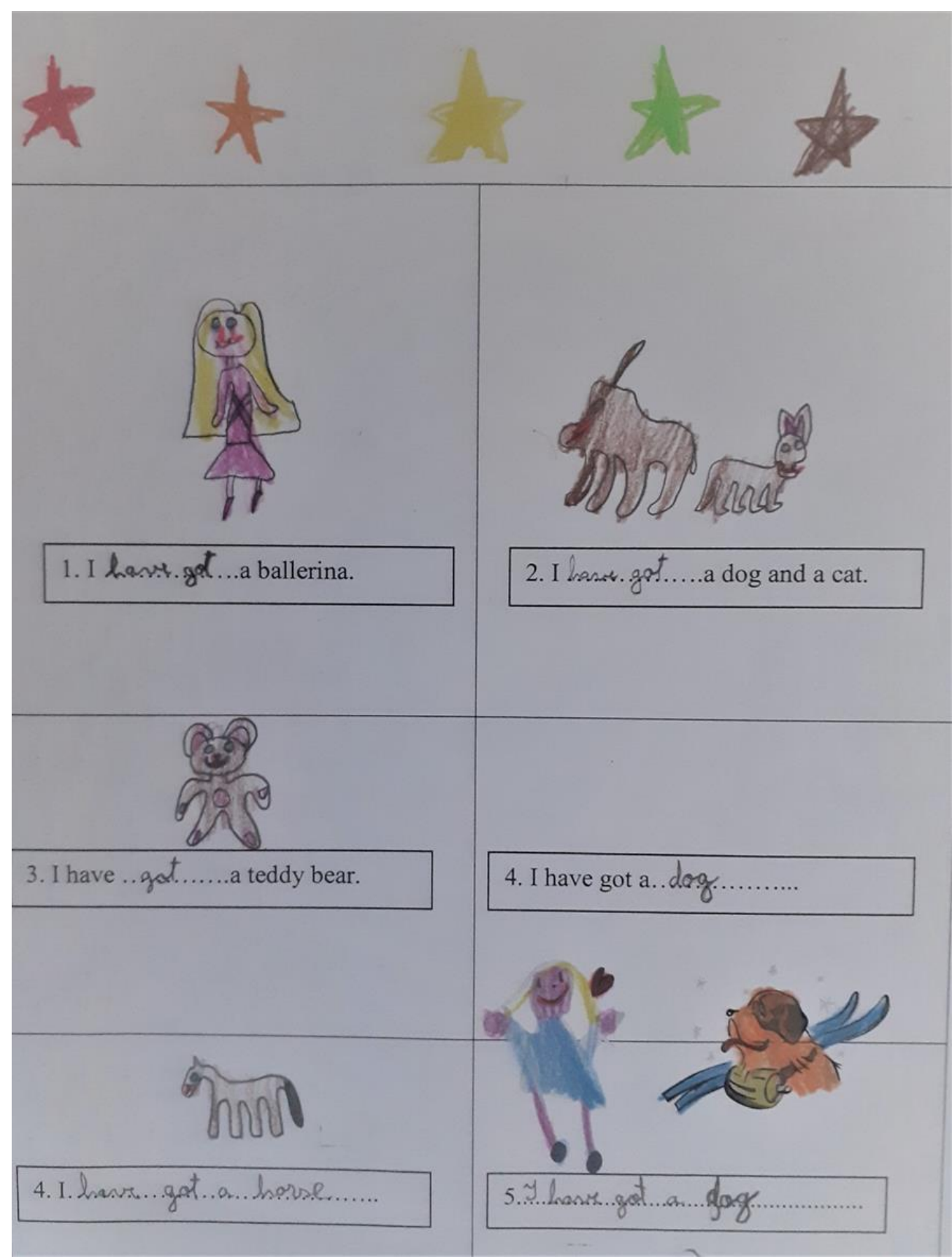

Figure 12. Teaching L2 Grammar through raising awareness of Morpheme Word Order: verb Have Got 


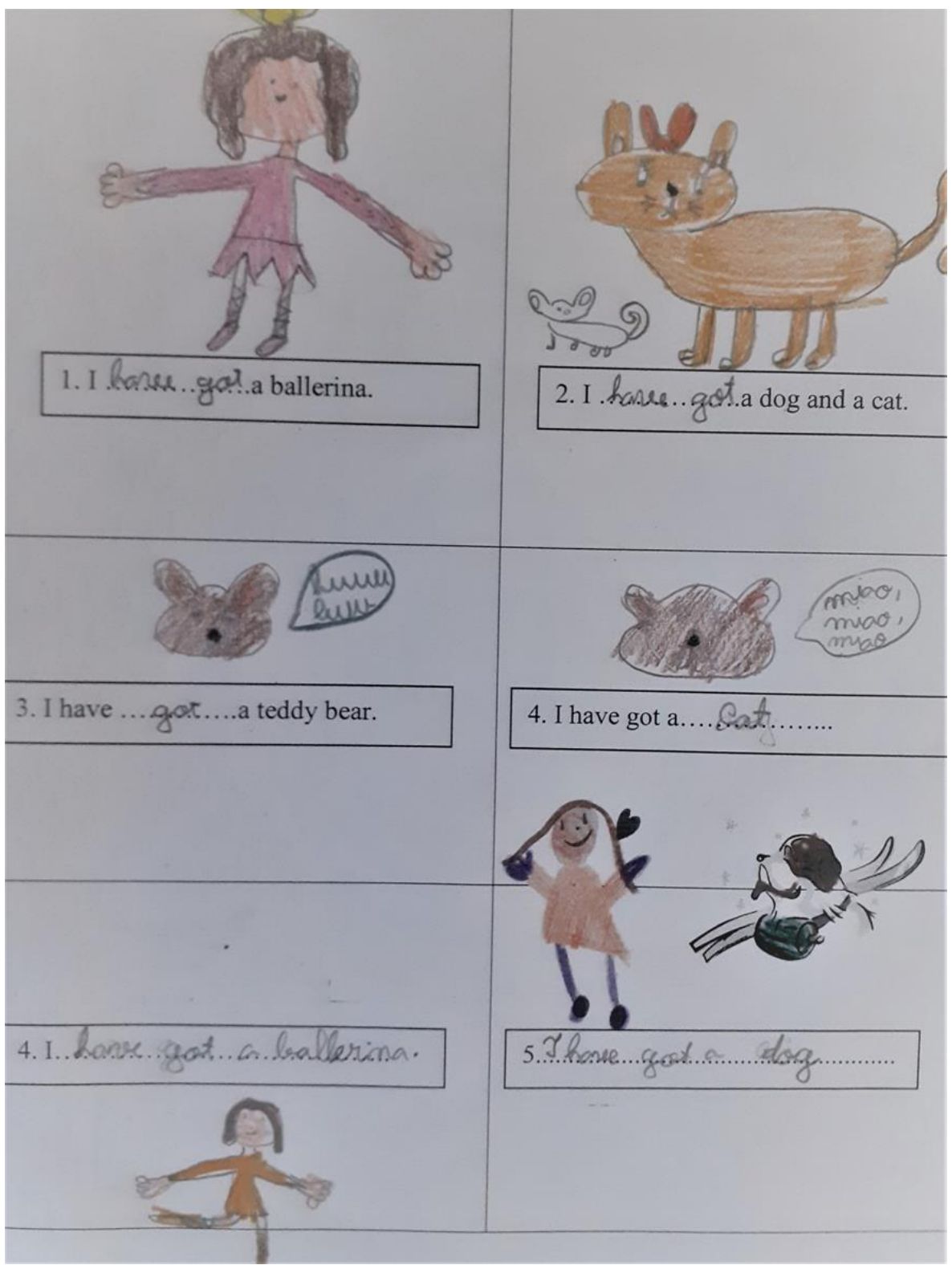

Figure 13. Teaching L2 Grammar thorugh raising awareness of Morpheme Word Order: verb Have Got

\section{Conclusions}

This study was set out to determine whether there is a viable path to argue for a case in second language acquisition within Primary English Language Teaching in Portugal, by looking into detail in morpheme worder acquisition in the English Language. Pupils' samples of work demonstrate that through language play and through na appeal to their preferences it is possible to teach syntax and grammar, namely 'I have got' and 'Prepositions', working fom the word level up to the sentence level, thus contributing for their English language fluency at an early age such as 7 years old. These are groundbreaking findings within the Portuguese context as there is a common disbelief it is not possible grammar in primary schools, seeing it merely as creating language awareness.

Reagarding the initial research questions, (1) does early English learning experience contribute to morpheme acquisition order and improves second grade primary puplis' English learning outcome? we found, based on the collected data, that the answer is 'yes'.

Concerning the research question (2), how can EFL Teachers of Young Learners best include this dimension in lesson planning, without causing frustration to Young Learners of English? it is believed by the authors of this study that 
the grammar dimension can and should be included in the curriculum for Teaching English to Young Learners through language play, which fosters (and does not hinder) second language acquisition.

This paper demonstrated that: if children are exposed to English as a medium of instruction, resorting to cross-curricular work and CLIL, similarly to bilingual education classrooms, children are able to acquire the necessary language structures to express themselves fully and fluently in English. This study also shed light into Young Learners' ability to express themselves in writing and go beyond speaking skills and singing songs in English. Singing chants in English is a valuable resource for "training the ear" /listening skills and productive skills such as practicing their pronounciation. What is more, this study expands the horizons in the field of English Language Teaching to Young Learners in that it argues for the full mastery of the language thus encompassing the four language skills in English langauge lessons. As a consequence, Teachers of English to Young Learners should take further continuous professional development opportunities and overcome the 'psychological barrier' that it is not possible to teach grammar and the 4 skills to Young Learners.

\section{Results and Implications}

The presented research is the first study within the Portuguese context to actually demonstrate that teaching morpheme order supports vocabulary and L2 acquisition. Our findings do set a viable pathway for future studies exploring having an "ear for language", the relationship between auditory skills and word learning. It offers a glimpse into the issue of language talent, while suggesting a possibility that training basic auditory skills such as language awareness activities can improve not only vocabulary learning but also gramar learning whereas enhancing academic achievement in English. In addition, it should be highlighted that visual materials such as flashcards, children's own toys, illustrations, bus or cinema timetables, newspapers, récipes, menus might be used to facilitate the L2 acquisition process. Therefore, pictures and realia are seen as a teaching tool in order to awaken the students 'imagination or capture their interest and reduce their language learning anxiety (Harmer, 2001; Harmer 2007; Ornelas, 2021), which leads to one of Krashen's premises in that is anxiety is reduced, L2 acquisition will take place 'spontaneously'.

Therefore, the present study was set out to determine to what extent can the gramatical features of the language be incorporated in the syllabus for English Language Teaching, thus preserving Young learners' engagement withn the language learning process. Therefore, in this study was possible to investigate the most innovative pedgogic approaches to contribute to 1) effective second langauge learning, thus clearly contributing to morpheme acquisition order and improves second grade primary puplis' English learning outcome and 2) shed light on how can EFL Teachers of Young Learners best include this dimension in lesson planning, without causing frustration to Young Learners of English. As such the present study sets out a viable path to fully teach the four key dimensions of English Language Teaching.

This carries implications for further Teacher Training Opportunities within Teaching English to Young Learners, so specialist English Language Teachers can 'reframe' their conceptual frameworks of refrence and open their minds to new teaching possibilities and incorporate these new teachings in their daily practice, thus preparing young learners of English to their future language challenges and helping to build new rapport across English language curriculum. By doing so Teacher of English to Young Learners are actually making a contribution to establishing a viable path for academic success.

\section{References}

Baetens-Beardsmore, H. (1999). In Marsh, Marsland, and Maljers, CLIL Initiatives for the Millennium: Report on the CEILINK Think-Tank. University Jyvaskyla, Jyvaskyla.

Baetens-Beardsmore, H. (Eds.) (1993). 'Introduction', in European Models of Bilingual Education, Multilingual Matters, Clevedon.

Baker, C. (2001). Foundations of Bilingual Education and Bilingualism (3rd ed.). Bilingual Education and Bilingualism 27. Multilingual Matters, ISBN 1-85359-524-1.

Ball, P., Kelly, K., \& Clegg, J. (2016). Putting CLIL into Practice. Oxford University Press, UK.

Barrett, M., Byram, M., Aroni, A., Golubeva, I., \& Jouhanneau, C. et al. (2021). A Portfolio of Competences for Democratic Culture: Younger Learners Version. Strasbourg: Council of Europe Publishing.

Bialystok, E. (2018). Bilingual Education for Young Children: Review of the Effects and Consequences. International Journal of Bilingual Education and Bilingualism, 21, 666-679. https://doi.org/10.1080/13670050.2016.1203859

Published by Sciedu Press 
Bosh, S., Veríssimo, J., \& Clashen, H. (2019). Inflectional morphology in bilingual language processing: an age-of-acquisition study. Language Acquisition, 26(3). https://doi.org/10.1080/10489223.2019.1570204

Cheep-Arani, R. A., \& Wasanasomsithi, P. (2015). Implementing Play-Based Language Learning with Children: From Potential to Practice. Innovation in Language Learning and Teaching, 141-159. https://doi.org/10.1057/9781137449757_10

Cook, G. (2000). Language Play, Language Learning. Oxford Applied Linguistics (1st ed.). ISBN-13: 978-0194421539. https://doi.org/10.1017/9781009024549

Coyle, D., \& Hood, P. (2010). CLIL: Content and Language Integrated Learning. Cambridge University Press. ISBN: 9780521112987.

Coyle, D., Holmes, B., \& King, L. (2009). Towards an intergrated curriculum: CLIL National Statement and Guidelines. Languages Company. Retrieved from http://www.languagescompany.com/images/stories/docs/news/clil_national_statement_and_guidelines.pdf

Cummins J. (1979). Linguistic interdependence and the educational development of bilingual children. Review of Educational Research, 49, 222-251. https://doi.org/10.3102/00346543049002222

Cummins J. (1981). Schooling and language minority students: A theoretical framework. Evaluation, Dissemination and Assessment Center, California State University; Los Angeles: The role of primary language development in promoting educational success for language minority students.

Cummins J. (2008). Teaching for transfer: Challenging the two solitudes assumption in bilingual education. In Cummins J, Hornberger NH, editors. Encyclopedia of language and education, 5. Bilingual education. 2. New York, NY: Spring Science + Business Media, pp. 65-75. https://doi.org/10.1007/978-0-387-30424-3_116

Cummins, J. (2011). Multilingualism in the English-language Classroom: Pedagogical Considerations. TESOL Quarterly.

Darasawang, P., \& Todd, R. (2012). The Effect of Policy on English Language Teaching at Secondary Schools in Thailand. https://doi.org/10.1075/veaw.g42.17dar

Djigunovic, H. (2012). Dynamics of learner affective development in early FLL. Studies in Second Language Learning and Teaching, 2(2). https://doi.org/10.14746/ssllt.2012.2.2.2

Duarte, J. (2016). Translanguaging in mainstream education: a sociocultural approach. International Journal of Bilingualism and Bilingual Education, 22(2). https://doi.org/10.1080/13670050.2016.1231774

Dulay, H. \& Burt, M. (1973). Shoudl We Teach Children Syntax? Language Learning, 23(2), 245-258. https://doi.org/10.1111/j.1467-1770.1973.tb00659.x

Dulay, H., \& Burt, M. (1974). Errors and Strategies in Child Second Language Acquisition. TESOL Quarterly, 8, 2. https://doi.org/10.2307/3585536

Ellis, R., \& Han, Y. (1998). Implicit knowledge, explicit knowledge and general language proficiency. Language Teaching Research, 2(1), 1-23. https://doi.org/10.1177/136216889800200102

Fledge, J. (2001). The $71 \mathrm{ffect}$ of experience on adults' acquisition of a second language. Studies in Second Language Acquisition, 23(4), 527-552. https://doi.org/10.1017/S0272263101004041

García, O. (2009). Bilingual Education in the 21st Century. Hoboken, NJ: Wiley-79. Blackwell.

Garcia, O., \& Leiva, C. (2013). Theorizing and Enacting Translanguaging for Social Justice. Heteroglossia as Practice and Pedagogy, pp. 199-216. https://doi.org/10.1007/978-94-007-7856-6_11

Gundarina, O., \& Simpson, J. (2021). A monolingual approach in na English primary school: practices and implications. Language and Education, 1-21. https://doi.org/10.1080/09500782.2021.1945084

Harmer, J. (2001). The practice of English language teaching (3rd ed.). Longman.

Harmer, J. (2007). How to teach English. Pearson Education Limited. https://doi.org/10.1093/elt/ccn029

Johnson, D., \& Johnson, T. (2006). Cooperative Learning and Social Interdependence Theory. Theory and Research on Small Groups (pp.9-35). https://doi.org/10.1007/0-306-47144-2_2

Jrank. (2010). Child Development Reference - Vol.6 - Play - What Is Play? The Importance of Play, Elements of Children's Play, Social Elements of Play. Net Industries, LLC. Retrieved September, 2010, from http://social.jrank.org/pages/492/Play.html 
Krashen, S. (1987). Principles and Practice in Second Language Acquisition. Prentice-Hall International.

Krashen, S. (1988). Second Language Acquisition and Second Language Learning. Prentice-Hall International.

Kwon, E. Y., \& Han, Z. (2008). Language transfer in child SLA: A longitudinal case study of a sequential bilingual. In Philip, J., Oliver, R. \& Mackey, A. (Eds.), Second Language Acquisition and the Younger Learner: Child's play. John Benjamins Publishing Company. https://doi.org/10.1075/lllt.23.18kwo

Lenneberg, E. (1967). Biological foundations of language. New York: John Wiley and Sons. https://doi.org/10.1080/21548331.1967.11707799

Lessow-Hurley, J. (2000). The Foundations of Dual Language Instruction. New York, Addison Wesley Longman, Inc.

Lucas, C. (2020). The Reading and Writing Connections in Developing Overall L2 Literacy: A Case Study. Languages, 5, 69. https://doi.org/10.3390/languages5040069

Lucas, C., Hood, P., \& Coyle, D. (2020). Blossoming in English: Preschool Children's Emergent Literacy Skills in English. Journal of Research in Childhood Education, 1-26. https://doi.org/10.1080/02568543.2020.1742256

Marsh, D., Cañado, M., \& Ráez-Padilla, J. (2015). CLIL in Action: Voices from the Classroom. Cambridge Scholars Publishing. ISBN (10): 1-4438-7557-0.

Mayberry, R. I. (1991). The Long-Lasting Advantage of Learning Sign Language in Childhood: Another Look at the Critical Period for Language Acquistion. Journal of Memory and Language, 30(4), 48. https://doi.org/10.1016/0749-596X(91)90018-F

Mayberry, R. I., \& Eichen, E. B. (1991). The long-lasting advantage of learning sign language in childhood: Another look at the critical period for language acquisition. Journal of Memory and Language, 30(4), 486-512. https://doi.org/10.1016/0749-596X(91)90018-F

Morini, G., \& Newman, S. (2019). Dónde está la ball? Examining the 72ffect of code switching on bilingual children's word recognition. Journal of Child Language, 46(6), 1238-1248. Cambridge University Press. https://doi.org/10.1017/S0305000919000400

Mourão, S. (2018). Play and peer interaction in a low-exposure foreign language-learning programme. Preschool bilingual education, pp 313-342. In M. Schwartz (eds.), Preschool Bilingual Education, Multilingual Education 25. https://doi.org/10.1007/978-3-319-77228-8_11

Newport, E. (1990). Maturational Constraints on Language Learning. Cognitive Science, 14, 11-28. https://doi.org/10.1207/s15516709cog1401_2

Nikolov, M., \& Djigunovic, J. M. (2011). All shades of every color: An overview of early teaching and learning of foreign languages. Annual Review of Applied Linguistics. https://doi.org/10.1017/S0267190511000183

Ornelas, A. (2021). Increasing reluctant students' spoken production through the use of guessing games in pairs in a 4th grade English as a foreign language classroom. Master Thesis. Faculdade de Letras, Universidade do Porto, Portugal.

Oyama, S. (1976). A sensitive period for the acquisition of a nonnative phonological system. Journal of Psycholinguistic Research, 5(3), 261. https://doi.org/10.1007/BF01067377

Pallier, C. (2003). Critical periods in language acquisition and language attrition. Unité de Neuroimagerie Cognitive, INSERM U562, SHFJ \& IFR 49, Orsay, France.

Pica, T. (2005). Second Language Acquisition Research and Applied Linguistics. Retrieved from https://repository.upenn.edu/gse_pubs/34

Pienemman, M., \& Johnston, G. (2008). Constructing na Acquisition-Based Procedure for Second Language Assessment. Studies in Second Language Acquisition, 10(2), 217-243. https://doi.org/10.1017/S0272263100007324

Ramos, J. (2018). Morpheme Order Studies: a descriptive study in English as a second language. Master Thesis in English Studies.Universidad del Pais Vasco. Retrieved from http://hdl.handle.net/10810/30138

Resnick, L., Asterhan, C., \& Clarke, S. (2015). Socializing Intelligence through academic talk and dialogue (pp.251-272) Publisher: AERA books. Editors: Lauren Resnick, Christa Asterhan, Sherice Clarke. https://doi.org/10.3102/978-0-935302-43-1 
Snow, C. E., Burns, M. S., \& Griffin, P. (eds.) (1998). Preventing reading difficulties in young children. Washington, DC: National Academy Press.

Veríssimo, J., Heyer, V., Jacob, G., \& Clahsen, H. (2017). Selective effects of age of acquisition on morphological priming: Evidence for a sensitive period. Language Acquisition, 25, 315-326. https://doi.org/10.1080/10489223.2017.1346104

Vygotsky, L. S. (1978). Mind in society: The development of higher psychological processes. London: Harvard University Press.

Whitebread, D., \& Coltman, P. (2015). Teaching and Learning in the Early Years (4th ed.). Routledge Taylor \& Francis Goup, ISBN 9780415722537. https://doi.org/10.4324/9781315858234

\section{Copyrights}

Copyright for this article is retained by the author(s), with first publication rights granted to the journal.

This is an open-access article distributed under the terms and conditions of the Creative Commons Attribution license (http://creativecommons.org/licenses/by/4.0/). 